\title{
Pathogenicity of Two Fungi; Trichoderma harzianum and Cladosporium herbarium on The Two-spotted Spider Mite; Tetranychus urticae Koch
}

\author{
A. M. Afifi ${ }^{1}$, E. M. A. El- Saiedy ${ }^{2}$ and Abeer M. Shaltout ${ }^{3}$ \\ ${ }^{1}$ Zoology and Agric. Nematology Dept., Faculty of Agriculture, Cairo University, Giza, Egypt \\ ${ }^{2}$ Plant Protection Dept., National Research Center, 12622 Dokki, Cairo Egypt \\ ${ }^{3}$ Plant Pathology Institute, Agric. Res. Center, Giza, Egypt
}

\begin{abstract}
Two fungi; Trichoderma harzianum and Cladosporium herbarium were isolated from dead bodies of the two-spotted spider mite Tetranychus urticae Koch. Pathogenicity of the two fungi against T. urticae were studied and evaluated under laboratory and semi-field conditions. Three fungal spore suspensions were prepared; T. harzianum $\left(2 \times 10^{6} \mathrm{spores} / \mathrm{ml}\right)$, C. herbarium $\left(1 \times 10^{6}\right.$ spores $\left./ \mathrm{ml}\right)$ and a mixture of both fungi $(50 \%: 50 \%)$. The effect of fungal spore suspensions on the deferent stages of $T$. urticae was studied at $30 \& 35^{\circ} \mathrm{C}$ and $90 \%$ R.H. The mortality percentages of all mite stages increased with prolonging the period after spraying. The mixture of the two fungi gave higher mortality than a single one after 3 and 7 days for all mite stages reaching $46.8 \%$ and $59.8 \%$ after 3 and 7 days respectively at $30^{\circ} \mathrm{C}$, while at $35^{\circ} \mathrm{C}$, it increased to $65.1 \%$ and $83.0 \%$ after the two periods respectively. Under semi-field conditions, the mean reduction in mite population resulted from using suspensions of $T$. harzianum and $C$. herbarium recorded 42.4 and $43.9 \%$ respectively after 10 days of spraying, while it increased to $58.2 \%$ when using the mixture of the two fungi. Both fungi T. harzianum and C. herbarium exhibited a positive effect in the pathogenicity of the two-spotted spider mite, T. urticae, but it is recommended to use a mixture of both fungi to obtain more efficient control.
\end{abstract}

KEY WORDS: Pathogenicity, fungi, Trichoderma harzianum, Cladosporium herbarium spider mite, Tetranychus urticae.

\section{INTRODUCTION}

The two-spotted spider mite Tetranychus urticae Koch is considered an economically important pest of commercial strawberry production. Its decreases plant vigor which eventually results in decrease fruit size and yield (Lola-luzd 2003). In 2004 and during the application of integrated pest management (IPM) program in strawberry farm, Badr district, Behira Governorate, Egypt, it was noted that, the population of $T$. urticae deeply declined in the greenhouses used for mass culturing the predatory mites Phytoseiulus persimilis (Athias-Henroit) and Amblyseius californicus (McGregor). This phenomenon encouraged us to collect dead bodies of T. urticae and examined in the laboratory, where the two fungi; Trichoderma harzianum and Cladosporium herbarium were isolated. Knowledge of mite diseases is still fragmentary, but in recent years, more attention has been paid to acaropathogens, because of the economic importance of many phytophagous mites. The entomo-pathogenic fungi play an important role in the regulation of phytophagous mite populations and sometimes to decimate it (Van der Geest et al, 2000) and concequently reduce the application of acaricides.In Egypt, climatic conditions are considered more suitable for fungal pathogens (Sewify, 1989). Several species of pathogenic fungi were applied against mite pests; Hirsutella thompsonii Fisher against the citrus rust mite, Phyllocoptruta oleivora (Ashmed) (McCoy, 1975 and Latge et al, 1988) against T. urticae (Hanna and Heikal, 1995) and against Aceria gurreronis (Kumar, 2006); Verticillium lecanii against Eutetranychus orientalis (Klein) (Sewify and Mabrouk, 1991) and Beauveria bassiana against T. urticae (Yousri, 1994; Hassan, 2003 and Afifi et al. 2004 \& 2006); The objective of this work was to study the pathogenicity of two fungi, $T$. harzianum and $C$. herbarium on T. urticae in the laboratory and semi-field conditions.

\section{MATERIALS AND METHODS}

\section{Fungi Isolation, Identification and Preparation:}

Dead bodies of $T$. urticae were collected from three greenhouses used for mass rearing and production of the predatory mites, Phytoseiulus persimilis (Athias-Henroit) and Amblyseius californicus (McGregor). For fungal isolation, the dead mites were surface sterilized by immersing it in $3.0 \%$ Sodium hypochloride solution and immediately left up, then rinsed in sterilized water. Sterilized mites were dried between two sterilized filter papers, and then transferred to Potato dextrose agar (PDA) medium. Inoculated (PDA) plates were incubated at $25 \pm 2^{\circ} \mathrm{C}$ and examined daily for occurrence of the fungal growth. The isolated fungi were purified using the single spore technique (Hildbrand, 1948). Detected fungi were transferred to slants of PDA medium and kept at $5^{\circ} \mathrm{C}$. Fungal isolates were identified at Mycology Research and Disease Survey, Dept., Plant Pathology, Research Institute, Agricultural Research Center, according to 
Bisset (1991) and Ellis (1993). A mycelial agar block from a stock culture of $T$. harzianum and $C$. herbarium was transferred each to a $9 \mathrm{~cm}$.-diameter Petri-dish of PDA. Cultures were grown at room temperature $\left(24 \pm 2^{\circ} \mathrm{C}\right)$ for ten days, then spores were liberated by gentle agitation with a sterile wire loop in the presence of $10 \mathrm{ml}$ of sterile water, followed by filtration through two layers of sterilized cheese cloth to reduce mycelium clumping. The concentration of fungal spores was determined using a haemocytometer, and the suspension was diluted with sterile water to inoculum levels of $2 \times 10^{6}$ and $1 \times 10^{6}$ spores $/ \mathrm{ml}$ for $T$. harzianum and $C$. herbarium, respectively.

Three fungal spore suspensions were prepared; T. harzianum $\left(2 \times 10^{6}\right.$ spores $\left./ \mathrm{ml}\right), C$. herbarium $\left(1 \times 10^{6}\right.$ spores $\left./ \mathrm{ml}\right)$ and a mixture of both fungi $(50 \% / 50 \%)$.

To study the effect of fungal spore suspensions on the deferent stages of $T$. urticae, sterilized potato leaf discs (1 inch diameter) were put on moist cotton wool pads placed in glass Petri-dishes, where few drops of water were added daily to maintain suitable moisture content. Ten leaf discs, each contained ten individuals of homogenous eggs or immatures or adult females of T. urticae. Ten replicates were used for each suspension, in addition to the check, which were treated with water only. Plant discs were treated by direct spray (spraying in the presence of the mite individuals) using a hand atomizer, then kept at incubators adjusted at $30^{\circ} \mathrm{C}, 35^{\circ} \mathrm{C}$ and $90 \%$ R.H. Mortality was determined after 3 and 7 days.

To study fungi effects at semi-field condition, 20 plastic pots $(10 \mathrm{~cm}$ diam. \& $15 \mathrm{~cm}$ high) cultivated with mite infected bean plants, were sprayed, five pots for each treatment, in addition to the check. The percentage of mite population reduction was determined after 3, 7 and 10 days according to the equation of Henderson and Tilton (1955).

\section{RESULTS AND DISCUSSION}

Data presented in Table 1 show that the mortality percentages of all mite stages increased after 7 days more than those after 3 days of fungal suspensions spraying. T. harzianum exhibited higher efficiency on eggs and immature stages of T. urticae, while $C$. herbarium was more effective to the adults. The mixture of the two fungi showed higher mortality after 3 and 7 days in all mite stages than that of either one alone. When this experiment was conducted at $35 \mathrm{C}^{\circ}$ and $90 \%$ R.H. (Table 2), the obtained results show that $T$. harzianum gave higher mortality on adults and immatures after 3 days than C. herbarium, while the latter gave higher mortality on eggs than the former. After 7 days, $C$. herbarium gave high mortality on mite adults and eggs. Mortality percentage was higher when the mixture of the two fungi was applied. However total mean mortality percentage of $T$. urticae was nearly greater when using $C$. herbarium especially at $35^{\circ} \mathrm{C}$.

Under semi-field conditions, the four submentioned treatments were applied on infested bean plants planted in plastic pots. Table (3) show that, the mixture of two fungi gave the highest population reduction percentage $(58.2 \%)$ followed by that of $C$. herbarium (42.4\%) then $T$. harzianum $(43.9 \%)$ after 10 days of spraying.

Therefore, it could be concluded that $C$. herbarium and $T$. harzianum have a positive effect in the pathogenicity of $T$. urticae, but using the mixture of both fungi is recommended to obtain more efficient results in controlling this noxious pest.

Lenteren (2000) stated that green-houses support favorable conditions for fast reproduction of pests and diseases, thus it demanded successive chemical treatments. About 100 species of beneficial organisms are commercially available for control all important mite and insect pests. Chandler and Van

Table (1): Effect of Trichoderma harzianum $\left(2 \times 10^{6}\right.$ spores $\left./ \mathrm{ml}\right)$ and Cladosporium herbarium $\left(1 \times 10^{6}\right.$ spores $\left./ \mathrm{ml}\right)$ and their mixture on the mortality percentages of Tetranychus urticae different stages at $30^{\circ} \mathrm{C}$ and $90 \%$ R.H.

\begin{tabular}{|c|c|c|c|c|c|}
\hline \multirow{2}{*}{$\begin{array}{l}\text { Days after } \\
\text { treatment }\end{array}$} & \multirow{2}{*}{ Mite stage } & \multicolumn{4}{|c|}{ (\%) Mortality after fungi treatments } \\
\hline & & T.harzianum & C. herbarium & T. harzianum + C. herbarium & Check \\
\hline \multirow{4}{*}{3 days } & Adult & 42.0 & 45.3 & 62.0 & 0.0 \\
\hline & Immature & 39.6 & 36.9 & 58.4 & 2.0 \\
\hline & Egg & 21.4 & 16.6 & 20.0 & 3.3 \\
\hline & Mean & 34.3 & 32.9 & 46.8 & 1.8 \\
\hline \multirow{4}{*}{7 days } & Adult & 62.4 & 63.3 & 72.0 & 4.5 \\
\hline & Immature & 45.0 & 47.1 & 65.7 & 0.6 \\
\hline & Egg & 25.4 & 23.1 & 41.5 & 13.3 \\
\hline & Mean & 44.3 & 44.5 & 59.8 & 6.2 \\
\hline
\end{tabular}


Table (2): Effect of Trichoderma harzianum $\left(2 \times 10^{6}\right.$ spores $\left./ \mathrm{ml}\right)$ and Cladosporium herbarium $\left(1 \times 10^{6}\right.$ spores $\left./ \mathrm{ml}\right)$ and their mixture on the mortality percentages of Tetranychus urticae different stages at $35^{\circ} \mathrm{C}$ and $90 \%$ R.H.

\begin{tabular}{rccccc}
\hline \multirow{2}{*}{$\begin{array}{c}\text { Days after } \\
\text { treatment }\end{array}$} & Mite stage & \multicolumn{4}{c}{$(\%)$ Mortality after fungi treatments } \\
\cline { 2 - 6 } & & T.harzianum & C. herbarium & T. harzianum + C. herbarium & Check \\
\hline \multirow{5}{*}{3 days } & Adult & 57.1 & 47.7 & 64.3 & 6.7 \\
\cline { 2 - 6 } & Immature & 46.5 & 42.8 & 57.1 & 6.7 \\
\cline { 2 - 6 } & Egg & 53.1 & 69.6 & 73.9 & 3.3 \\
\cline { 2 - 6 } & Mean & 52.2 & 53.4 & 65.1 & 5.6 \\
\hline \multirow{3}{*}{7 days } & Adult & 75.5 & 81.1 & 81.2 & 11.7 \\
\cline { 2 - 6 } & Immature & 60.7 & 60.7 & 67.8 & 6.1 \\
\cline { 2 - 6 } & Egg & 68.3 & 78.6 & 99.9 & 8.6 \\
\cline { 2 - 6 } & Mean & 68.1 & 73.5 & 83.0 & \\
\hline
\end{tabular}

Table (3): Effect of Trichoderma harzianum ( $2 \times 10^{6}$ spores $\left./ \mathrm{ml}\right)$, Cladosporium herbarium ( $1 \times 10^{6}$ spores $\left./ \mathrm{ml}\right)$ and their mixture on the population of Tetranychus urticae at semi- field conditions

\begin{tabular}{ccccc}
\hline \multirow{2}{*}{ Fungus } & \multicolumn{3}{c}{ (\%) Reduction after } & $\begin{array}{c}\text { Mean }(\%) \\
\text { reduction }\end{array}$ \\
\cline { 2 - 4 } T. harzianum & 3days & 7 days & 10 days & 42.4 \\
\hline C. herbarium & 34.1 & 46.8 & 46.3 & 43.9 \\
\hline Fungi mixture & 34.8 & 48.5 & 48.5 & 58.2 \\
\hline
\end{tabular}

der Geest (2006) indicated that the best documented pathogens of Acari are fungi; close to 60 species of fungi have been reported infesting at least 70 species of acarines across nearly all orders.

In Brazil, Van der Geest et al, (2002) isolated pathogenic fungus Cladosporium $s p$. from the eriophyid mite Retracus johnstoni Keifer (Phytoptidae) and cultured it in Potato-dextrose agar. Moreover, Kovach (1996) and Lola-Luz (2003) reported that the fungus T. harzianum could control some plant diseases and not harmful to mammals and other animals. It attacked the fungus Botrytis cinerea which causes gray mould disease in strawberries fruits and prevents it from developing .Now, manufacturing of various formulations of these biocontrol agents has been going on.

\section{REFERENCES}

Afifi, A. M., Mabrouk, A. M. and Asran, A. A., 2004. Effect of the entomo-pathogenic fungus, Beauveria bassiana on the two-spotted spider mite, Tetranychus urticae Koch. Egypt. J. Agric. Res. 82: 47-55.

Afifi, A. M., Mabrouk, A. M. and Asran, A. A., 2006. Effect of the entomo-pathogenic fungus, Beauveria bassiana on three acarine pests. XII Inter. Congress of Acarology, Amster-dam, The Netherlands.

Bisset, J., 1991. A revision of the genus
Trichoderma. III Section Pachybasium. Can. J. Bot. 69: 2373-2417.

Chandler, D. and Van der Geest, L. P. S., 2006. Diseases of mites and ticks. an introduction. XII Inter. Congress of Acarology, Amsterdam, The Netherlands.

Ellis, M. B., 1993. Dematiaceous Hypho-mycetes. CAB International Walling-ford. U. K.

Hanna, A. I. and Heikal, I. H., 1995. Biological control of Tetranychus urticae Koch by the fungus Hirsutella thompsonii var synnematosa on kidney bean plants in a greenhouse. Egypt $\mathrm{J}$. Appl. Sci.10 (6): 221-224.

Hassan, R. H. M., 2003. Studies on fungal pathogens for controlling the two-spotted spider mite Tetranychus urticae Koch. M. Sc. Thesis, Fac. of Agric. Cairo University. PP: 74.

Henderson, C. F. and Tilton, E. W., 1955. Tests with acaricides against the brown wheat mite. J. Econ. Entomol. 48: 157-161.

Hildbrand, A. A., 1948. An occurrence of brown stem rot of soybean in Ontario. Sci Agric., 28: 261-263.

Kovach, J., 1996. Using bees to deliver a biological control agent to control gray mould of strawberry. Strawberry IPM Update Fall 1996. 3: $1-11$.

Kumar, P. S., 2006. Hirsutella thompsonii as a mycoacaricide for Aceria guerr-eronis on coconut in India: Research, development and 
other aspects. XII Inter. Congress of Acarology, Amsterdam, The Netherlands.

Latge, P., Cabrea-Cabera, R. L. and Prevost, M. C., 1988. Microcycle condition in Hirsutella thompsonii Canad. J. Microbiol. 34 (5): 625-630.

Lenteren, J. C. V., 2000. A greenhouse without pesticides: fact or fantasy? Crop Protection. 19: 375-384.

Lola-Luz, D., 2003. Integrated pest and disease control on Indoor and outdoor strawberry in Ireland. Teagasc, Dublin, Ireland. 2003: pp.41.

McCoy, C. W., 1975. Large scale production of the fungal pathogen Hirsutella thompsonii in submerged culture and its formulation for application in the field. Entomo-phaga, 20: 229240.

Sewify, G. H., 1989. Evaluation of the entomopathogenic fungus Beauveria bassiana (Balsamo) Vuillemin for controlling three lepidopterous pests infesting maize in Egypt. J. Appl. Biol. Control. 9: 203-210.

Sewify, G. H. and Mabrouk, A. M., 1991. The susceptibility of different stages of the citrus brown mite Eutetranychus orientalis (Klein) (Acarina: Tetrany-chidae) to the entomopathogenic fungus Verticillium lecanii (Zimm) Viegas. Egypt. J. Appl. Biol. Control. 1: 89-92.

Van der Geest, L. P.S., DeMoraes, G. J., Navia, D. and Tanzini, M.R., 2002. New record of pathogenic fungi in mites (Arachnida: Acari) from Brazil. Neotropical Entomology. 31:1-5.

Van der Geest, L. P. S., Elliot, S. L., Breeuwer, J. A. and Beerling, E. A. M., 2000. Diseases of mites. Exp. and Appl. Acarology, 24: 497-560.

Yousri, H., 1994. Labpratory evaluation of Beauveria bassiana (Balsamo) vuill. as a pathogen of adult female stage of the twospotted spider mite Tetranychus urticae Koch. Egypt. J. Appl. Sci. 9:380-387. 